\title{
放射線が奏効したメルケル細胞癌
}

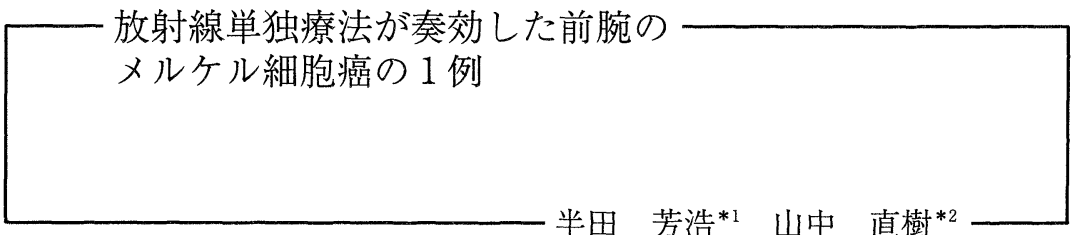

半田 芳浩*1 山中 直樹*

\section{A case of Merkel cell carcinoma of the antebrachium successfully treated with only radiotherapy}

Yoshihiro HANDA *1, Naoki YAMANAKA *2

*1 Department of Dermatology, Nagoya University Groduate School of Medicine

*2 Division of Dermatology, Tokoname Municipal Hospital

We report a case of an 88 year-old man with Merkel cell carcinoma. He noticed a subcutaneous induration on his left antebrachium about three months before visiting Tokoname municipal hospital. The tumor was firm, light red, dome-shaped with the size of $25 \times 25 \mathrm{~mm}$ in diameter. The biopsy specimen revealed nests of tumor cells with round nuclei and poor cytoplasm localized in the middle dermis to subcutaneous fatty tissue and did not extend into the epidermis. Electron microscopy demonstrated dense core granules in the intracellular spaces of the tumor cells. From the features mentioned above, we diagnosed his nodule as Merkel cell carcinoma. We chose the treatment of electron beam therapy $(6 \mathrm{MeV})$ alone to the primary lesion and left axillary lymph nodes in place of surgical treatment because of his age and past history of myocardial infarction. The tumor completely disappeared when the total amount of irradiation had been 51 Gy. We reviewed 46 reported cases of Merkel cell carcinoma located in the extrimity and discussed the effectiveness of radiotherapy alone carried out in 12 reported cases with the tumor in Japan. [Skin Cancer (Japan) 2000 ; 15: 168-174]

Key words : Merkel cell carcinoma, Extremity, Antebrachium, Radiotherapy, Electron beam therapy

\section{はじめに}

メルケル細胞癌は高齢者の顔面に好発する皮 膚原発の腫瘍で, 局所再発・リンパ節転移・遠

*1 名古屋大学大学院医学研究科皮虐病態学分野

*2 常滑市民病院皮雐科
隔転移をきたしやすい悪性度の高い腫瘍であ る。その臨床像は単発性で, 赤色〜暗紫色の表 面平滑なドーム状の結節ないし浸潤性の局面と してあらわれることが多い1。確立された治療 法はなく，通常は原発巣の広範囲切除と所属リ ンパ節の郭清が行われ, 後療法として放射線療 法や化学療法が施行されることが多い。 


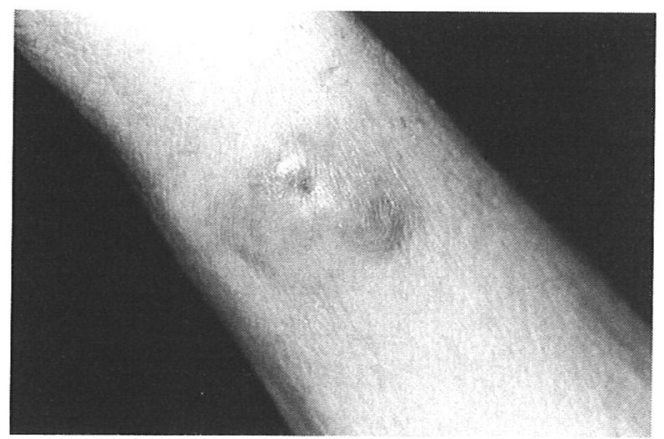

図 1. 臨床像

左前腕遠位尺側の淡紅色斑．中央の陥凹は生 検による瘕痕

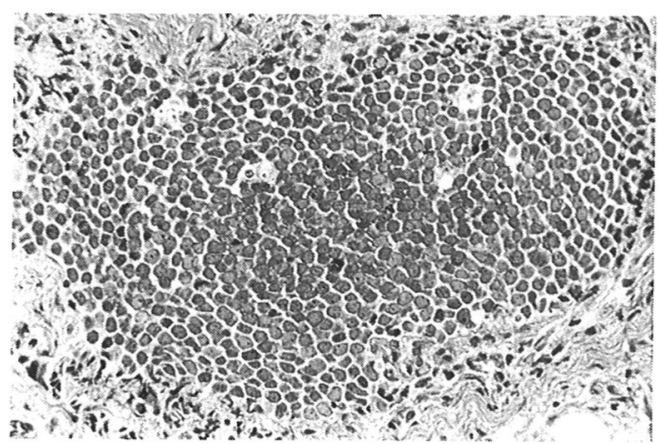

図 3.病理組織強拡大像

腫瘍細胞は円形大型核を有し, 細胞質にそしい

今回我々は放射線単独療法が奏効した左前腕 に発生したメルケル細胞癌の 1 例を経験したの で報告する。

\section{症例}

患 者：88 歳, 男性

初 診: 1999 年 11 月 4 日

主 訴：左前腕の淡紅色結節

家族歴：特記すべきことなし。

既往歴：72 歳時より前立腺肥大症, 75 歳時 に後壁心筋梗塞, 老人性白内障, 79 歳時に前壁 心筋梗塞。

現病歴：1999 年 8 月頃より左前腕に瘙痒を伴 う皮下硬結を触れるようになった。瘙痒はステ ロイド剤の外用で軽快したが，皮下硬結は徐々 に増大してきた。

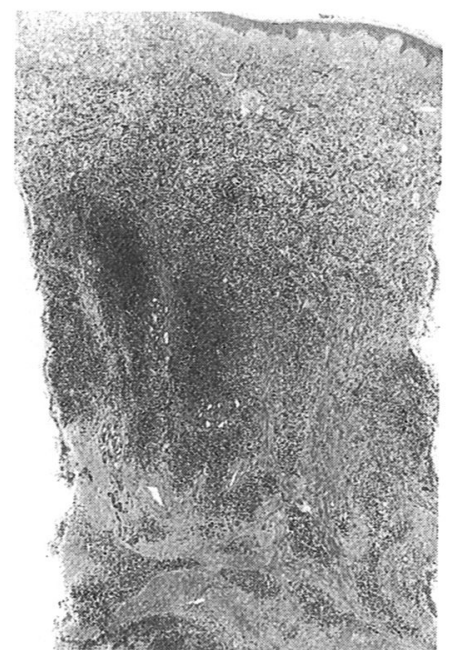

図 2.病理組織像

彌慢性に増殖する腫瘍細胞．部分的に充実性 胞巣を形成する

現 症：左前腕遠位尺側に直径 $25 \mathrm{~mm}$ のやや ドーム状に隆起した弾性硬の結節を触知した。 皮膚表面は平滑，淡紅色であったが，糜爛や出 血は認めなかった（図１）。下床との可動性は良 好で，自発痛や圧痛はなかった。腋窩リンパ節 は触知しなかった。

入院時検査所見：生化学，血液一般検査にて 異常はなかった。血清 neuron specific enolase (以下 $\mathrm{NSE}$ ) 值は $5.4 \mathrm{ng} / \mathrm{m} l$ (正常 $10 \mathrm{ng} / \mathrm{m} l$ 以下) と正常範囲内であった。Ga シンチグラムでは 異常集積像を認めず，CTではリンパ節の腫大 および遠隔転移を示す所見はなかった。

病理組織学的所見：腫瘍は真皮中層から皮下 脂肪組織にかけて存在し，表皮との連続性はな かった。腫瘍細胞は彌慢性に増殖し，部分的に は充実性胞巣を形成していた (図 2 )。個々の腫 瘍細胞は小型で細胞質にそしく，核は大型で円 形を呈し，核小体は明暸であった（図３）。ま た，多数の核分裂像を認めた。

免疫組織化学的所見: 腫瘍細胞は抗 cytokeratin 抗体 (CAM5.2), 抗 chromogranin 抗体に陽性で抗 NSE 抗体, 抗 CD3 抗体, 抗 CD20 抗体には陰性であった。 


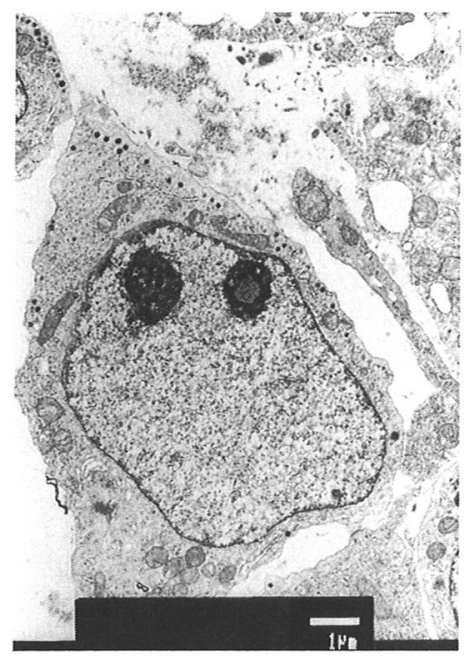

図 4.電子顕微鏡像

細胞質内に 1 列縦隊の端正な顆粒(有芯顆粒) を認める

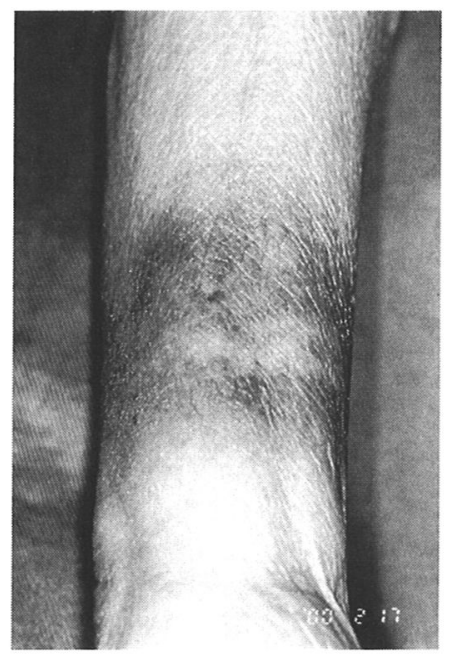

図 6. 放射線照射後の臨床像 皮下結節は触知されず，色素沈着を残す

電子顕微鏡所見：腫瘍細胞質内に 1 列に並ん だ顆粒を認めた（図 4)。それらは80 100nm 前 後で 1 層の限界膜に囲まれていた。高電子密度 の coreを有しており，有芯顆粒と考えた（図 5 )。

治療および経過：高齢であること，部位的に 広範囲切除が困難なこと, および心筋梗塞の既 往歴があることを考慮して外科的切除は施行せ

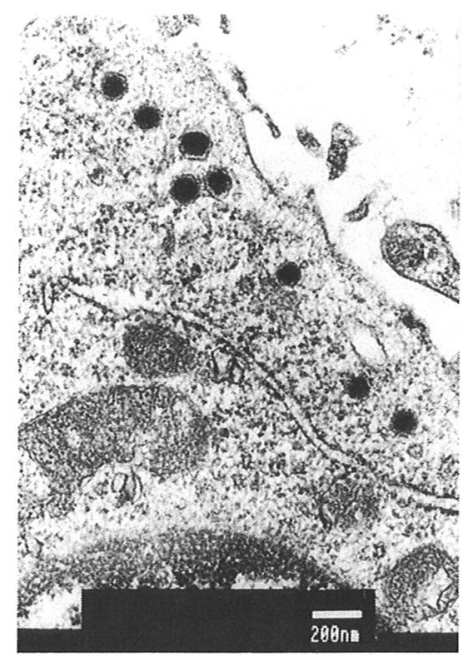

図 5. 有芯顆粒拡大像

80 100nm 前後で 1 層の限界膜に囲まれ，高 電子密度の core を有する

ずに, 放射線単独療法を選択した。腫瘍部位に $6 \mathrm{MeV}$ の電子線を $3 \mathrm{~Gy} /$ 日で計 $51 \mathrm{~Gy}$, 左腋窩リ ンパ節に計 $30 \mathrm{~Gy}$ を照射した。皮下結節は触知 されなくなり, 色素沈着を残すのみとなった （図 6 ）。生検にて軽度の形質細胞の浸潤を認め るのみで, 腫瘍細胞はみられなかった。放射線 照射終了後 9 力月を経過した現在まで再発, 転 移は認められない。

\section{考案}

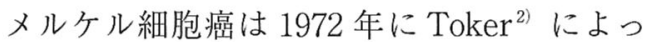
て "trabecular carcinoma of the skin”として報 告されたのが最初である。その後 1978 年に Tang ら $^{3)}$ が電子顕微鏡で, 腫瘍細胞の細胞質 内に有芯顆粒を認女て以来，メルケル細胞由来 の癌であると考えられるようになった。

萱島ら ${ }^{4)}$ が 1995 年に皮膚科・眼科研修施設 1584 施設を対象として行ったアンケート調査 の結果， 110 施設での計 174 例の本腫瘍を集計 した。これは当時文献的に検索できた症例数の 約 2 倍であったと報告している。萱島らの集計 によると年齢は, 17 ～ 103 歳 (平均 75.3 歳), 
性別は, 男性 48 例, 女性 126 例（男性：女性 =1：2.6）であった。発生部位は，174 例中顔 面が 126 例と最も多く，その内訳は煩部が 51 例, 眼瞼部が 41 例であった。我々が文献的に検 索したところ, 本邦では 1981 年の Iwasaki ら ${ }^{5)}$ の報告を嗃矢として現在までに 317 例の報告が あり，この数から考えて本腫瘍は従来いわれて きたような稀な腫瘍ではない。四肢発生例は自 験例を含めて 46 例で ${ }^{6) \sim 49)}$ (表 1 ), それらの年 齢は $43 \sim 97$ 歳 (平均 70.3 歳), 性別は男性 29 例，女性 17 例（男性：女性=1.7:1）であった。 四肢発生例 46 例中, 下肢に生じた例が 27 例, 上肢に生じた例が 19 例で，そのうち前腕発生 例は自験例を含めて 4 例のみであった。した がって自験例は非常に稀な部位に発生した症例 である。

Gould ら ${ }^{50)}$ は，本腫瘍を腫瘍細胞の組織学的 形態から，1）結合織に区画された trabecular patternを呈する腫瘍細胞からなる trabecular type, 2 ) 腫瘍が small neoplastic cell の瀰漫性 の浸潤からなる small cell type，3 ) 前二者の中 間程度の大きさの細胞が large solid nest を形成 し，その辺縁に trabecular patternを示す intermediate cell type の 3 覀型に分類した。こ の分類によれば，自験例は intermediate cell typeに相当した。

本腫瘍の免疫組織化学染色において, NSEの 発現が感度の高いマーカーとして利用されてき た。抗 NSE 抗体染色は, 野田ら ${ }^{18)}$ は 30 例中 26 例 (86.7\%) に, 梅澤ら ${ }^{51)}$ は 50 例中 43 例 (86.0\%) に陽性であったと報告しているが，自 験例では陰性であった。

本腫瘍の診断に最も重要視されているのは, 電子顕微鏡像における有芯顆粒の存在である。 有芯顆粒は, 中心に50 150nm の電子密度の高 い部分を有する, 単位膜に包まれた直径 70 250nm の顆粒で, 自験例でも確認された。 ただし有芯顆粒は，転移性カルチノイド，転移 性神経芽細胞腫, 皮膚神経芽細胞腫, 転移性燕 麦細胞癌でも認められるため ${ }^{22}$, 疾患特異性は
表 1．本邦四肢発生例（2000 年 6 月まで）

\begin{tabular}{|c|c|c|c|c|c|}
\hline 報告年 & 報告者 & 年橉 & 性別 & 発生部位 & 文献 \\
\hline \multirow[t]{2}{*}{1983} & 赤松ら & 66 & 男 & 左下腿 & 6 \\
\hline & Nakashima 5 & 83 & 男 & 右时 & 7 \\
\hline 1986 & Iwafuchiら & 68 & 男 & 左下腿 & 8 \\
\hline 1988 & 竹本ら & 43 & 女 & 左肘 & 9 \\
\hline \multirow{4}{*}{1989} & 野見山ら & 79 & 男 & 右时 & 10 \\
\hline & 中山ら & 84 & 女 & 右足関節 & 11 \\
\hline & 松岡ら & 62 & 男 & 左足背 & 12 \\
\hline & 加藤ら & 61 & 男 & 左下腿 & 13 \\
\hline 1990 & 宮城島ら & 68 & 男 & 左前睕 & 14 \\
\hline \multirow{3}{*}{1991} & 渡辺ら & 62 & 男 & 左下腿 & 15 \\
\hline & 井内ら & 85 & 男 & 左上婏 & 16 \\
\hline & 松田ら & 83 & 女 & 右上腕 & 17 \\
\hline \multirow[t]{3}{*}{1992} & 野田ら & 83 & 男 & 左上腕 & 18 \\
\hline & 板村ら & 63 & 男 & 左下腿 & 19 \\
\hline & 大林ら & 66 & 男 & 右下腿 & 20 \\
\hline \multirow[t]{3}{*}{1993} & 鶴田ら & 72 & 男 & 左足底 & 21 \\
\hline & 川㚼ら & 49 & 女 & 左大腿 & 22 \\
\hline & 藤井ら & 86 & 男 & 左上腕 & 23 \\
\hline \multirow[t]{3}{*}{1994} & 原田ら & 64 & 女 & 右第 V指 & 24 \\
\hline & 大沼ら & 55 & 女 & 左肘 & 25 \\
\hline & 高橋ら & 44 & 男 & 右大腿 & 26 \\
\hline \multirow[t]{2}{*}{1995} & 橋本ら & 69 & 女 & 左上腕 & 27 \\
\hline & 大久保ら & 86 & 男 & 左足背 & 28 \\
\hline \multirow[t]{6}{*}{1996} & 栗村ら & 50 & 男 & 右膝蔵 & 29 \\
\hline & 山ロら & 58 & 女 & 右时 & 30 \\
\hline & 小林ら & 77 & 女 & 右下腿 & 31 \\
\hline & 衛藤 & 62 & 女 & 左下腿 & 32 \\
\hline & 宮脇ら & 48 & 女 & 右榻蓋 & 33 \\
\hline & 吉井ら & 82 & 男 & 右大腿 & 34 \\
\hline \multirow[t]{3}{*}{1997} & Ohnishiら & 81 & 男 & 右手背 & 35 \\
\hline & 山本ら & 73 & 女 & 右上腕 & 36 \\
\hline & 福山ら & 68 & 男 & 左下腿 & 37 \\
\hline \multirow[t]{6}{*}{1998} & 石亀ら & 81 & 女 & 右下腿 & 38 \\
\hline & & 50 & 男 & 左大腿 & 38 \\
\hline & 大井ら & 81 & 女 & 左前腕 & 39 \\
\hline & 斉藤ら & 86 & 男 & 右大腿 & 40 \\
\hline & 本田ら & 97 & 女 & 右下腿 & 41 \\
\hline & 早川ら & 79 & 女 & 右足底 & 42 \\
\hline \multirow[t]{4}{*}{1999} & 村上ら & 78 & 男 & 右前踴 & 43 \\
\hline & 板井ら & 75 & 女 & 右第 | 指 & 44 \\
\hline & 阿南ら & 84 & 男 & 右滕蓋 & 45 \\
\hline & 草野ら & 62 & 男 & 左肘 & 46 \\
\hline \multirow[t]{4}{*}{2000} & 柴田ら & 62 & 男 & 右睖関節 & 47 \\
\hline & 関ら & 63 & 男 & 左下腿 & 48 \\
\hline & 前田ら & 70 & 男 & 右足背 & 49 \\
\hline & 半田ら & 88 & 男 & 左前踛 & 自験仍 \\
\hline
\end{tabular}


表 2. 初発病巣に対して放射線単独療法を施行した本邦報告例

\begin{tabular}{|c|c|c|c|c|c|c|c|c|c|c|}
\hline 報告年 & 報告者 & 年齢 & 性別 & 発生部位 & リンパ館転移 & 放射線の種類 & 照射部位及び吸収線量 & 照射部再発 & 転帰 & 文献 \\
\hline 1981 & Iwasaki & 80 & 女 & 左頬 & 照射後数日してあり & コバルト & 堙箅に52Gy & なし & 脳出血にて死亡 & 5 \\
\hline 1987 & 八島ら & 88 & 女 & 左㚘页 & なし & 電子線 & 腫圗に15Gy & なし & 12力月觡在 & 54 \\
\hline 1993 & 吾妻ら & 67 & 女 & 右頬 & なし & - & 腫瑒 & なし & - & 55 \\
\hline 1995 & 青木ら & 90 & 女 & 右眉毛 & 入院時よりあり & コバルト & 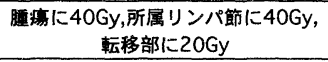 & なし & 遠隔転移にて死亡 & 56 \\
\hline 1995 & 岡田ら & 83 & 女 & 左頬 & 照射終了3カ月後にあり & - & 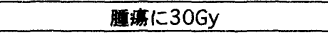 & あり & 遇隔転移にて死亡 & 57 \\
\hline 1997 & 村田ら & 89 & 女 & 左㚘页 & なし & 奄子線 & 䐗䍡に60Gy & なし & - & 58 \\
\hline 1997 & 那須ら & 88 & 女 & 左上眼瞼 & なし & コバルト,電子線 & 各々腈癔に25Gy,13Gy & なし & 老衰にて死亡 & 59 \\
\hline 1998 & 和田ら & 89 & 女 & 右煩 & - & 電子線 & 腫恤に60Gy & - & - & 60 \\
\hline 1999 & 小野ら & 78 & 女 & 右下眼瞼緑 & - & 電子線 & 腫确に50Gy & - & - & 61 \\
\hline 2000 & 池田ら & 86 & 女 & 右外耳道 & 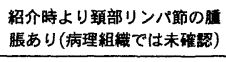 & X線 & $\begin{array}{c}\text { 堙瘭に48Gy, } \\
\text { 所属リンパ節に48Gy } \\
\end{array}$ & なし & 肺真菌症にて死亡 & 62 \\
\hline 2000 & 長井ら & 86 & 男 & 頭 & - & - & 腫境に71Gy & - & 摍小煩向にて経過視祭中 & 63 \\
\hline 2000 & 自験例 & 88 & 男 & 左前腕 & なし & 電子線 & $\begin{array}{c}\text { 腫罟に51Gy, } \\
\text { 所属リンパ節に30Gy }\end{array}$ & なし & 6力月健在 & 自験例 \\
\hline
\end{tabular}

ない。したがって，その存在だけでは本腫瘍の 診断は確定しない。

治療法としては，未だガイドラインは作成さ れておらず，症例により広範囲切除術およびリ ンパ節郭清術, 放射線療法, 化学療法など様々 な治療が行われている。放射線療法は切除後の 術後照射として施行されることが多く，第 1 選 択の治療法としての報告は少ない。Hasle ${ }^{53)}$ は 放射線単独療法を行った 8 症例では全く局所再 発はみられず，遠隔転移も 8 例中 2 例に認めた のみであったことから，放射線単独療法の有効 性を報告している。

我々が検索したところ本邦では初発病巣に対 して放射線単独療法を施行した症例は，自験例

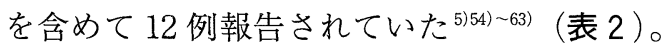
11 例の線源としてはX線, 電子線, コバルトが 使用され，吸収線量は 15〜71Gy であった。1 例 に腫瘍の局所再発を認めたのみで，この療法の 有効性は明らかである。したがってリンパ節転 移に対しても，原発腫瘍と同様放射線療法が有 効と考えられる。12例中遠隔転移により死亡し たのは 2 例であった。これらは，照射部以外に 転移が拡大していたことが剖検にて確認されて いる。自験例ではリンパ節転移を疑わせる所見 は認めなかったが，所属リンパ節への予防的照 射を施行した。本腫瘍は後述のように高率にリ ンパ節転移を認めることより，予防的に所属り ンパ節への照射も施行すべきと考える。
本腫瘍の予後は不良で，局所再発率 14 51\%，リンパ節転移 22～55\%，遠隔転移 14 36\%である ${ }^{64)}$ 。一方，生検後の自然消退例 もあり，これは女性に多い ${ }^{36)} 。 3$ 年生存率は男 性 35.6\%，女性 67.6\% と女性の方が予後がよ (65)。予後不良の因子としては，1）若年者，2） 頭澒部や体幹発症，3 ) 男性，4）局所再発や所 属リンパ節転移，5 ) 全身疾患の合併がある ${ }^{66)}$ 。 本腫瘍の局所再発までの期間は 1 54 カ月（平 均 10.1 力月）であり ${ }^{67)}$, 自験例も放射線療法が 奏効したとはいえ，今後の注意深い経過観察が 必要である。

本腫瘍は放射線感受性が高いので, 広範囲切 除が困難な場合，高齢や基礎疾患のため手術不 可能な場合，手術侵襲が大きく機能や外観の保 持が困難な場合は，放射線治療を積極的に試み るべきである。

本症例は第 16 回日本皮膚悪性腫瘍学会学術大会 （2000 年 7 月 1 日，旭川市）にて発表した。

\section{文献}

1）真鍋俊明，福岡恵子：皮虐に発生する神経内分泌 腫瘍。病理と臨床, 17:1283-1289, 1999.

2) Toker, C. : Trabecular carcinoma of the skin. Arch. Dermatol., 105: 107-110, 1972.

3 ) Tang, C.K., Toker, C. : Trabecular carcinoma of the skin, An ultrastructural study. Cancer, 42 : 
2311-2321, 1978.

4) 萱島研一：高齢者の腫瘍性疾患，(3) メルケル細胞 癌. MB Derma, 7 :45-52, 1998.

5 ) Iwasaki, H., Mitsui, T., Kikuchi, M., et al. : Neuroendocrine carcinoma (Trabecular carcinoma) of the skin with ectopic ACTH production. Cancer, 48: 753-756, 1981.

6 ）赤松徹, 守田英治, 伊藤達也, 他：皮膚小細胞癌 の 1 例. 皮膚臨床, $25: 495-499,1983$.

7) Nakashima, N., Goto, K., Takeuchi, J., et al. : Case report of neuroendocrine carcinoma of the skin, histochemical and electron microscopic study. Virchows Arch. [Pathol. Anat.], 401:261-273, 1983.

8) Iwafuchi, M., Watanabe, H., Ishihara, N., et al. : A neuroendocrine (Merkel) cell carcinoma with coexisting intraepidermal squamous cell carcinoma of the skin, Its growth accelerated by an extrinsic factor. Acta. Pathol. Jpn., 36 : 1099-1108, 1986.

9) 竹本剛, 福原敏行: 左肘部腫瘤 (Merkel cell carcinoma)。広島医学, 41:1977, 1988.

10）野見山朋彦，末永義則：Dermoid cystに合併して 生じた Merkel cell carcinoma. 日皮会誌，99：362， 1989.

11）中山英俊, 岡田しのぶ, 三原基之, 他：メルケル 細胞癌とボーエン病の併存した 1 例. 日皮会誌, $99: 362,1989$.

12）松岡芳隆, 山口文雄, 浅島裕雄, 他: Bowen 病の 病変中に生じた trabecular carcinoma. 日皮会誌, $99: 362,1989$.

13 ）加藤拓, 高橋久雄, 遠藤富士乗, 他：皮膚 Merkel 細胞癌一特に小円形細胞腫瘍との比較一. J. Jpn. Soc. Clin. Cytol., 28: 510-515, 1989.

14）宮城島拓人, 岡田和夫, 永坂敦, 他：化学療法に 著効を示した転移性メルケル細胞腫の 1 例. 癌の 臨床, 36:75-79, 1990.

15）渡辺匡子, 荒木由起夫, 菅原信: Merkel cell tumorの一例.日皮会誌, 101:347, 1991.

16）井内康輝, 武田晋平, 沖田肇, 他：皮膚のメルケ 儿細胞癌. 広島医学, 44:973-974, 1991.

17）松田実, 篠崎登, 氏家久, 他：異なった経過を とったメルケル細胞癌の 2 例. 日本臨床外科医学 会雑誌, $52: 2208-2209,1991$.

18）野田佳子，柴田郷子，一木幹生，他：Merkel cell carcinoma. 西日皮膚, 54:443-447, 1992.

19）板村論子, 三原一郎, 井上奈津彦, 他：広範な転 移を認めたメルケル細胞癌. 臨皮, 46:1095-1100, 1992.

20）大林千穂, 今井幸弘, 伊東恭子, 他：ボウエン病
を合併したメルケル細胞癌の 1 例. 病院病理, 10 : 143,1992

21）鶴田大輔, 持田和伸, 中川浩一, 他：砒素中毒患 者の足底に生じた紅色腫瘤. 日本皮膚病理組織学 会会誌, 9:26-30, 1993.

22）川畑勉, 城間寛, 大田治, 他: 術後 10 年経過して 肺転移を認めたメルケル細胞癌の 1 例. 沖縄医学 会雑誌, 30:123, 1993.

23 ) 藤井昌一, 大河内敏行, 西井孝, 他：上腕部に発 生したメルケル細胞癌の 1 例. 臨整外, 28:12811284, 1993.

24）原田研, 高橋正明, 遠藤尚孝：右小指に生じたメ ルケル細胞癌の 1 例. 皮膚臨床, 36:1340-1341, 1994.

25）大沼利恵，森口暢子, 馬場直子, 他：左肘関節外 側部に生じたメルケル細胞癌の 1 例. 臨皮，48： 923-925, 1994.

26）高橋玲, 奧山隆三, 重城博一, 他：アテローマに 発生した Merkel 細胞癌の 1 例. 癌の臨床, 40： 1043-1047, 1994.

27 ）橋本一郎，中西秀樹，荒瀬誠治，他：Merkel cell carcinoma の 1 例. 皮膚臨床, 37：642-643, 1995.

28）大久保幸子, 村田浩, 小口真司, 他: Bowen 病と eccrine fibroadenoma様所見を伴った Merkel 細胞 癌. Skin Cancer, 10:224-228, 1995.

29）栗村理恵，伊藤治夫，楠山法子，他：化学療法が 奏効したメルケル細胞癌の転移例. 臨皮, 50：635637, 1996.

30）山口英郎，池田和人，兼子泰行，他：右肘皮下に 生じたメルケル細胞癌の 1 例. Skin Cancer, 11：811, 1996.

31 ）小林美礼, 倉知貴志郎, 井上千津子：メルケル細 胞癌. 皮膚, 38:170-171, 1996.

$32 ）$ 衛藤光：メルケル細胞癌由来細胞株一細胞株化の 臨床的意義一。細胞, 28:406-407, 1996.

33 ）宮脇剛司，木下行洋，松浦慎太郎，他：膝蓋部义 ルケル細胞癌の 1 例, 一広範囲切除と再建一. 形 成外科, 39:1247-1251, 1996.

34 ) 吉井章, 萱島研一, 小野友道: Bowen 病病変部に 生じた小結節が Merkel cell carcinoma であった 1 例. Skin Cancer, 11:349-353, 1996.

35 ) Ohnishi, Y., Murakami, S., Ohtsuka, H., et al. : Merkel cell carcinoma and multiple Bowen's disease : Incidental association or possible relationship to inorganic arsenic exposure?. J. Dermatol., 24 :310-316, 1997.

36）山本真理，稲田礼子，末廣晃宏，他：生検後自然 消退傾向を示した Merkel cell carcinoma の 1 例. Skin Cancer, 12:86-90, 1997. 
37）福山薰子, 橋本健治, 清水由晴, 他：CEA 陽性で あったメルケル細胞癌の 1 例. Skin Cancer, 12： 96-100, 1997.

38）石亀廣樹, 大谷津恭之, 石川雄一, 他：下肢に発 生したメルケル細胞癌の剖検例。日病理会誌, 87 :510, 1998.

39）大井章史, 中西功夫 : Merkel cell carcinoma の 1 例. 病院病理, $15: 101,1998$.

40）斉藤研二, 薄木晶子, 村田洋三, 他 : パンツ型紅 斑と血小板減少を示したメルケル細胞癌の 1 例. 日皮会誌, $108: 878,1998$.

41）本田栄, 上田修平, 出来尾哲, 他：メルケル細胞 癌に有棘細胞癌が併存した 1 例．西日皮膚，60： 402, 1998.

42）早川あずさ, 河京美, 竹中秀也, 他：有棘細胞癌 とメルケル細胞癌を併発した砒素角化症の 1 例.

西日皮膚， $60: 402,1998$.

43 ）村上圭子, 小篠隆久, 瀬川郁雄, 他：前腕に発生 したメルケル細胞癌の 1 例．日皮会誌，109:689， 1999.

44）板井淑子, 竹内吉男, 市川義之, 他：指に生じた Merkel cell carcinoma の 1 例. 日皮会誌，109： 937-938, 1999.

45）阿南隆，三浦芳子，岡本壽男，他：下肢に生じた メルケル細胞癌の 1 例. 大分県立病院医学雑誌, 28:174-176, 1999.

46）草野衣吏子, 河井正晶, 三浦優子, 他: 左肘窩に 生じたメルケル細胞癌の 1 例。日皮会誌，109： 1505, 1999.

47）柴田真一, 岡島加代子, 大原國章: Bowen 病病変 部に生じた Merkel 細胞癌. 日皮会誌, 110:719, 2000.

48）関詩穂，塩原順子，市川健，他：メルケル細胞癌 の 1 例. 第 16 回日本皮膚悪性腫瘍学会総会・学術 大会 プログラム・抄録集：108, 2000.

49）前田俊一, 坂本忠秀, 緒方克己, 他: 多発性ボー エン病に合併したメルケル細胞癌の 1 例. 第 16 回日本皮膚悪性腫瘍学会総会・学術大会プログ ラム・抄録集：109, 2000.

50 ) Gould, V.E., Moll, R., Moll, I., et al. : Biology of disease, Neuroendocrine (Merkel) cells of the skin : Hyperplasias, dysplasias, and neoplasms. Lab. Invest., $52: 334-353,1985$.

51）梅澤慶紀, 市川眞喜子, 平田雅子, 他：自然消退 傾向が認められた Merkel cell tumor．皮膚病診
療, 17:553-556, 1995.

$52 ）$ 今泉勤, 小関伸, 武田光, 他：メルケル細胞癌の 1 例. 皮膚臨床, 37:1861-1864, 1995.

53) Hasle, H. : Merkel cell carcinoma : The role of primary treatment with radiotherapy. Clin. Oncol., 3:114-116, 1991.

54 ）八島豊, 旭正一, 占部治邦: Merkel cell tumor. 西日皮虐，49:207-208, 1987.

55 ）吾妻美子, 大浦一, 野本正志, 他: メルケル細胞 癌の 1 例. 高知学園短期大学紀要, $24: 763-770$, 1993.

56）青木明恵, 山田晴義, 木村俊次 : Merkel 細胞癌の 1 例. 臨皮, 49:1117-1120, 1995.

57）岡田裕之, 渡辺晋一, 高橋久: Merkel cell carcinoma の 1 例, 抗 keratin 抗体の診断における 有用性. 日皮会誌，105：1445-1450, 1995 。

58 ）村田恭子, 前口瑞恵, 乃木田俊辰, 他 : 放射線単 独療法が奏効したメルケル細胞癌の 1 例. 臨皮, $51: 373-376,1997$.

59 ）那須佐知子, 橋田巌, 桜井英幸, 他: 放射線治療 が奏効した上眼瞼発生のメルケル細胞癌の 1 例.

Kitakanto Med. J., 47 : 91-94, 1997.

60）和田崇, 村田明広, 大槻匠, 他: 放射線治療が著 効したメルケル細胞癌の 1 例. 日皮会誌, 108： 1194, 1998.

61）小野浩子, 入交珪子, 新倉仁：メルケル細胞癌の 1 例. 日皮会誌, $109: 213,1999$.

62）池田真有子, 緒方喜美子, 近澤真紀, 他：右外耳 道に発生した Merkel cell carcinoma. 第 16 回日本 皮膚悪性腫瘍学会総会・学術大会プログラム・抄 録集：109, 2000.

$63 ）$ 長井泰樹，草間美紀，大森一範，他：Merkel cell carcinoma の 1 例. 日皮会誌, $110: 1171,2000$.

64 ）出光俊郎, 小菅綾子, 山田朋子, 他：メルケル細 胞癌一単純切除で再発, 転移をみない 1 例一. 皮 膚臨床, 38:123-127, 1996.

65) Hitchcock, C.L., Bland, K.I., Laney III , R.G., et al. : Neuroendocrine (Merkel cell) carcinoma of the skin, Its natural history, diagnosis, and treatment. Ann. Surg., 207 : 201-207, 1988.

66) Shaw, J.H.F., Rumball, E. : Merkel cell tumor : clinical behaviour and treatment. Br. J. Surg., 78 : 138-142, 1991.

67）石倉多美子，岡田保典：Merkel 細胞癌の 1 例. 臨 皮, 49:189-192, 1995. 